\title{
Assessing the Role of Transport in the Achievement of Maternal Mortality Reduction in Ghana
}

\author{
Patrick Fiagbe \\ Department of Information Systems and Decision Sciences \\ KNUST School of Business \\ Kwame Nkrumah University of Science \& Technology \\ Kumasi, Ghana \\ E-mail: pfkwame@gmail.com \\ David Asamoah \\ Department of Information Systems and Decision Sciences \\ KNUST School of Business \\ Kwame Nkrumah University of Science \& Technology \\ Kumasi, Ghana \\ E-mail: dasamoah.ksb@knust.edu.gh \\ Francis Tabi Oduro \\ Department of Mathematics \\ Kwame Nkrumah University of Science and Technology \\ Kumasi, Ghana \\ E-mail: francistoduro@yahoo.co.uk
}

Received: October 9, 2011

Accepted: November 18, 2011

Published: March 1, 2012

doi:10.5539/ijbm.v7n5p256

URL: http://dx.doi.org/10.5539/ijbm.v7n5p256

\begin{abstract}
Purpose: this study seeks to find the role and impact of transport's intervention in the achievement of the maternal mortality reduction in Ghana. The study used a number of approaches including case study, descriptive and exploratory approaches, and all these were adopted to gain a better understanding on the role of transport in the achievement of maternal death reduction. The study revealed that good vehicles and road infrastructure are perceived as a key link between potential accessibility and actual utilization of maternal health services. Again finding out the possibility of achieving zero maternal death in the municipality by the year 2015, health management staff perceived that it is likely to be achieved in Ghana; a little deviation from the report by African countries' MDG Africa Steering Group.
\end{abstract}

Keywords: Maternal mortality, Maternal health, Transportation, Millennium development goals, Ghana

\section{Introduction}

Every minute of every day, a woman in the world dies as a result of complications arising during pregnancy and childbirth (United Nations International Children Emergency Fund [UNICEF], 2008). The majority of these deaths are avoidable and transport has a critical role to play in achieving the Millennium Development Goal (MDG) 5: reducing maternal mortality by three-quarters from its 1990 level.

Maternal mortality refers to those deaths which are caused by complications due to pregnancy or childbirth and it is one of the most sensitive indicators of the health disparity between richer and poorer nations. These complications may be experienced during pregnancy or delivery itself, or may occur up to 42 days following 
childbirth (World Health Organization [WHO], 1992). The women who die are usually in the prime of their lives and, most often, have other children and other dependants. Developing countries stand the greatest risk of having obstetric complications which constitute the leading cause of death of women of reproductive age claiming the lives of an estimated 529,000 each year (Freedman et al, 2003).

The lifetime risk of dying due to maternal health causes is about one in six in the poorest countries, compared with about one in 30,000 in the Western World (Ronsmans and Graham, 2006). According to WHO (2007) each year, more than 536,000 women die due to complications developed during pregnancy and childbirth. Yet death from pregnancy-related causes represents one of the most preventable categories of female death worldwide.

Transport plays a critical role in the effective and efficient delivery of health care enabling people to access services and health workers to reach communities, especially in sparsely populated rural areas (Babinard \& Roberts, 2006). In Ghana, for example, many people in remote areas live a long distance from health facilities. Poor families walk for hours to reach health facilities either because they cannot afford the transport cost or because they cannot wait for limited, slow and/or uncomfortable transportation services as a result of roads being in poor condition.

It is becoming accepted that poor access to transport may play a role in maternal deaths and conditions such as fistula, but there is little research available on the veracity of this assertion and what may be the effective interventions. In fact, little mention is made with regards to the causes of maternal death and it relationship with transport. It is against this background that this study sought to determine the role and impact of transport related intervention in the achievement of maternal mortality reduction in Ghana, using the Asante Akim North Municipality of the Ashanti Region as case study. Specific objectives of the study included the investigation of transport availability and access in maternal health services. Finally, the study also aimed at identifying the challenges associated with current health transport management.

\section{Literature Review}

This section discusses the relevant theories on the subject matter and is divided into three sections. The first section considers literature on the Millennium Development Goals. Detailed information and issues regarding Millennium Development Goal Five which is a major focus of the study is presented in the second section. The last section reviewed concepts and theories on current transport models.

\subsection{Millennium Development Goal}

The Millennium Development Goals (MDGs) are eight international development goals that one hundred and ninety two (192) United Nations member states and at least 23 international organizations have agreed to achieve by the year 2015. In 2001, recognizing the need to assist impoverished nations more aggressively, UN member states adopted targets. The MDGs aim to spur development by improving social and economic conditions in the world's poorest countries (Wikipedia, 2009). All major international organizations as well as many civil society and private sector organizations supported the call to cut extreme poverty in half by 2015 . To make the commitments more manageable, eight (8) MDGs were selected, and a time limit for reaching the goals was set to 2015 to underline the urgency of the commitments (Wikipedia, 2009).

\subsubsection{The Millennium Development Goal Five - Improve Maternal Health}

Motherhood is a hazardous endeavor in many parts of the world. A woman living in sub-Saharan Africa has a 1 in 16 chance of dying in pregnancy or childbirth (United Nations Permanent Forum [UNPF], 2006). Worldwide, nearly 600,000 women between the ages of 15 and 49 die every year as a result of complications arising from pregnancy and childbirth. A total of $99 \%$ of all maternal deaths unfortunately occurs in developing countries, where $85 \%$ of the population lives. More than half of these deaths occur in sub-Saharan Africa and one third in South Asia. The maternal mortality ratio in developing countries is 450 maternal deaths per 100000 live births versus 9 in developed countries (WHO, 2007).

The death of a woman during pregnancy or childbirth is not only a health issue but also a matter of social injustice. The inclusion of maternal death reduction in the Millennium Development Goals (MDGs) highlights the renewed global commitment to this issue. For MDG5, countries have committed to reduce the maternal mortality ratio by three quarters between 1990 and 2015. However, achieving the goal of reducing 1990 maternal mortality ratios by 75 percent by 2015 or, even coming close, will require extraordinary efforts by the international community, the civil sector, and local governments. 


\subsection{Causes of Maternal Death}

Of the estimated 536,000 maternal deaths worldwide in 2005, developing countries accounted for more than 99 per cent. About half of the maternal deaths $(265,000)$ occurred in sub-Saharan Africa alone, with a third of them $(187,000)$ occurring in South Asia. Thus, sub-Saharan Africa and South Asia accounted for 84 per cent of global maternal deaths (UNICEF, 2008). Developing countries stand the greatest risk of having obstetric complications which is the leading cause of death of women of reproductive age claiming the lives of an estimated 529,000 each year (Freedman, 2003). The majority of these deaths, however, are preventable.

More than $70 \%$ of maternal deaths are due to five major complications: hemorrhage (34\%), infection (16\%), complications of unsafe abortion (4\%), Anaemia (4\%), hypertension (9\%) and obstructed labour (4\%) and other causes $(30 \%)$. There are also direct and indirect determinants of maternal death. Indirect determinants are defined as pre-existing diseases or diseases that develop during pregnancy (not related to direct obstetric determinants) that are aggravated by the physiological effects of pregnancy; the principal indirect determinants in many settings include anaemia, malaria, hepatitis and diabetes (Gelband et al., 2001).

\subsection{Impact of Maternal Death}

For each of the over five hundred thousand maternal deaths that occur yearly worldwide, an estimated 30 to 50 women suffer pregnancy-related health problems such as vesico-vaginal fistulae, infertility, and depression that can be permanently debilitating (WHO, 2001). Women in the developing world have a 1 in 48 chance of dying from pregnancy-related causes; the ratio in developed countries is 1 in 1,800 (WHO, 2001). Therefore the beneficial effects of reducing maternal mortality are of great relevance. Investments in safe motherhood not only improve a woman's health and the health of her family but also increase labour supply, productive capacity, and economic well-being of communities. Children whose mothers die or are disabled in childbearing have vastly diminished prospects of leading a productive life (World Bank, 1999). In addition to the health and economic rationale for ensuring maternal and reproductive health is a compelling human rights dimension to reducing death and illness associated with pregnancy and childbirth. Maternal and reproductive health has been codified in multiple international covenants (Cook, Dickens, Wilson \& Scarrow, 2001)).

\subsection{The Three Delay Model}

The "three delays" model developed by Thaddeus and Maine (1994) identifies delays in seeking, reaching, and receiving care as the key factors contributing to maternal death. The Model is a framework which explains the social factors responsible for maternal death. It set out key time periods in peri-natal complications during which delays can occur that have direct consequences for maternal and neonatal survival. According to (United Nations Population Fund [UNFPA], 2004) women who die in childbirth are likely to experience one of the three delays. Although not directly specified, the transport and mobility of pregnant women are clearly key components of the three delays model of maternal mortality that is pertinent in low-income countries.

$1^{\text {st }}$ Delay: Delay in Seeking Care

The First Delay is delay in deciding to seek care. It is related to having the knowledge to recognize a life threatening problem and making the decision to go for care, for example in respect of an obstetric complication (Thaddeus and Maine, 1994). Sometimes this occurs because of fear of the hospital or the costs that may result from professional care, lack of recognition that there is a problem, and lack of an available decision maker.

$2^{\text {nd }}$ Delay: Delay in identifying and reaching Medical Facility

The Second Delay occurs after the decision to seek care has been made. It is a delay in actually reaching the care facility and is usually the result of lack of infrastructure and difficulty in transport. The delay in reaching care results from inaccessibility of health services due to distance, lack of money, or other barriers to access. Again the poor roads that connect villages to health centers and the limited transportation options available make it difficult for women to reach the help they need.

$3^{\text {rd }}$ Delay: Delay in receipt of Adequate Treatment

The Third Delay is in obtaining care once the woman has reached the facility. It also refers to problems in content and quality of maternal health care services. Inadequacy of resources contributes to this delay model and this may be due to one or a chain of the following events: shortage of medical supplies, lack of equipment, prepayment policies, poor staffing or lack of trained personnel, and incompetence of the available staff or an operating theatre which result in women waiting for many hours at the referral centre. 


\subsection{Rural Transport Structure}

According to the World Bank report on rural roads and transport (2000), 70\% of the world's population lives in rural areas. The World Bank defines rural transport as all transport activities that take place at local government and community household levels. It comprises both motorized and non-motorized transport and rural transport infrastructure (e.g. roads). Most literature on transport in developing countries describe rural transport infrastructure as in bad condition, seasonally passable and poorly maintained. This constrains access as well as social and economic development (Airey, 1992; Nancollas, 1999).

Within the rural travel and transport sub-sector, men and women's experiences of transport and transport services differ. This is because they have different roles, constraints, options, needs and also priorities. Majority of transportation in the rural areas is done on foot and by head load. Women particularly, have to travel long distances to reach fuel wood supplies, health facilities and markets and they do not have access to means of transport besides walking and head loading.

The extent to which the transport burden on women can be improved will depend on the policies affecting rural development and the role of women in the planning of transport and social services. Women in labor can spend several hours travelling on a makeshift stretcher and over difficult terrain that can induce other health complications for the mother and child. Where access to roads is unavailable, delays of several days are often encountered as families try to raise the money necessary to pay for hiring a vehicle to transport the patient. Emergency transport costs are an overwhelming financial burden for families and this applies even over short distances. Hamlin (2004) argues that the delays in access to health services caused by the difficulties in raising money are one of the important contributors to the occurrence of obstetric fistula and the increased vulnerability among Ethiopian women in Africa. The bias towards infrastructure and large-scale transport still exists in national governments and donor agencies, and is reflected in terms of budgets, personnel and professional training (Hanson, 2004).

\section{Methodology}

The study used a number of approaches including case study, descriptive and exploratory approaches, and all these were adopted to gain a better understanding on the role of transport in the achievement of maternal death reduction. The main motivation for selecting the case study areas was because the chosen municipality has had the largest recorded maternal mortality for the past three years. Non-probability and convenience sampling techniques were used to collect data. The study used a total sample size of 410 made up of 380 pregnant women and 30 health management professionals. Questionnaires and interviews were the instruments used to collect primary data.

\subsection{Overview of study area}

The Asante- Akim North Municipality is one of the 27 districts in the Ashanti Region. The Municipality covers about $5.6 \%$ of the total land area of the Ashanti Region. It covers an area of 1361 sq.km with an estimated population of 170,882 (Ghana Health Service Ashanti Region, [GHS AR], 2009). There are 115 communities and 18 Community-based Health Planning and Services (CHPS) zones in the Municipality. The main forms of commercial transport are passenger buses and taxis. The Municipal Administration and the decentralized departments mainly use pickups, which also exist in the municipal. Motorcycles are also used extensively. Tractors and bicycles are the main forms of transport in the relatively remote Afram Plains area. A first class road from Accra to Kumasi passes through Konongo-Odumasi which is the capital of the municipality. A second-class road stretches from Konongo to Agogo. It is about 30 kilometres. The remaining roads are feeder roads created by vehicles and are found mainly in the Afram Plains. The Afram Plains area is virtually inaccessible during the rainy season.

The municipality under study has the largest recorded maternal mortality for the past three years round. Institutional maternal mortality stands at eight, nine and seven in the years 2007, 2008 and 2009 respectively (GHS AR, 2009). The health administration currently has two vehicles. One pick up aged over eight years and one ambulance aged over ten years received from a donor agency early in the year 2009 (GHS AR, 2009). Besides, the health administration has thirteen motorbikes which are basically used at the sub- municipality level to support health delivery services.

\section{Analysis and Discussion of Results}

This section presents the results and findings of the study. The findings are presented under specific headings: background characteristics of pregnant women and health management staff, reasons for seeking maternal health 
services, availability of transport for maternal health services and challenges of health service transport management system.

\subsection{Availability of Transport for Maternal Health Services (MHS)}

Table 1 shows that, majority of the respondents specifically, - 55.8\% of pregnant women and $36.7 \%$ of health management respondents described the transportation services for maternal health services as being good. Thirty two percent $(31.6 \%)$ of pregnant women respondents also indicated that transport availability was fair whereas $43.3 \%$ of health staff respondents stated same. Nearly thirteen percent $(12.6 \%)$ of pregnant women and a fifth $(20.0 \%)$ of health management respondents rated the availability of transport as poor.

\subsection{Type of Transport used to access Maternal Health Services (MHS)}

Public transport was identified as the main form of transport used to access maternal health service, $65.8 \%$ of pregnant women respondents and $56.7 \%$ of health management respondent's stated public transport as the main transport type. The next transport mode was walking: $28.9 \%$ of pregnant women and $26.6 \%$ of health management respondents attested to walking to health facilities to receive maternal services. About four percent (3.7\%) of pregnant women respondents and $6.7 \%$ of health management respondents used personal cars to access maternal health service. The fourth mode of transport used was motor bikes, $1.6 \%$ of pregnant women and $10.0 \%$ of health management attested to this mode of transport.

\subsection{Possibility of Achieving Zero Maternal Deaths}

When asked if there was the possibility of achieving zero maternal death, $46 \%$ of health management staff held that it was very likely. An equal percent each (27.0\%) stated that the zero maternal deaths target could be achieved and could not be achieved respectively.

\subsection{State of Roads Linking Health Facilities}

As many as $54.4 \%$ of the pregnant women respondents actually ranked the state of road network linking health facilities as good with $36.7 \%$ of the health management respondents holding the same opinion. Thirty two percent of pregnant women respondents felt that roads were in fair shape whilst $43.3 \%$ of health staff respondents also supported this assertion. One in five $(20 \%)$ of health management respondents described the state of road as poor with $13.7 \%$ of pregnant women respondents stating same.

\subsection{State of Vehicles and Roads as Maternal hazards}

The views of respondents; were to establish whether the state of vehicles or state of road contributed to maternal hazards. As much as $50.5 \%$ and $54.7 \%$ of the respondents rated poor state of vehicles and roads as very important contributory factors to maternal hazard, $14.2 \%$ and $10.5 \%$ also rated to be important, $14.2 \%$ and $11.65 \%$ rated to be average and interestingly, it was found that $21.1 \%$ and $23.2 \%$ rated vehicles and poor roads respectively as not being relevant to maternal health services.

In addition $80 \%$ and $37.7 \%$ of health management respondents rated poor state of vehicles and roads as very important contributory factors to maternal hazard, nearly three percent and forty three percent was also rated to be important and nearly three percent and twenty percent rated to be average.

\subsection{Operation of Transport Management System}

When health management staffs respondents were asked if there was a transport operation system in place, $40 \%$ of them answered in the affirmative whereas $60 \%$ replied in the negative. Similarly, 4 out of $10(40 \%)$ stated that they managed transport resources whilst $60 \%$ of them did not handle any transport resources. Twenty seven percent of health management respondents held that budgets were available for transport management. Conversely, $56.7 \%$ of respondents answered that there were no funds budgeted for transport operations whilst $16.7 \%$ could not tell.

The challenges perceived in transport management by health management staff are inadequate vehicles, aged vehicles and poor road networks respectively.

\section{Discussion of findings}

\subsection{Critical role of Transport in Maternal Services}

The critical role played by transport in the delivery of health services and for that matter maternal health services is of great relevance as was revealed from the findings of the study. As indicated in the study, good vehicles and road infrastructure are perceived by both pregnant women and health management staff as a key link between potential accessibility and actual utilization of maternal health services. This is confirmed by Babinard and Roberts (2006), who also found that transport enables patients to access services and enables health workers to 
reach communities, especially in sparsely populated rural areas. Again in Tanzania, a study conducted revealed that sixty three percent of the pregnant women who died after reaching a hospital had travelled 10 kilometers or more for treatment attesting to the critical role of transport with regard to maternal health services (Stekelenburg, 2004)

\subsection{Transport type used in accessing Maternal Health Services (MHS)}

To assess the transport type used in accessing maternal health services, findings from the study indicated that the primary form of transport for pregnant women in accessing health services is public transportation (See section 4.4). The study also revealed the perceived existence of good state of roads from the various sub-municipalities to health facilities in the case study municipality. This would in turn, allow public transportation services which are purely privately operated to be extended to those places. According to Borghi, Ensor, Neupane and Tiwari (2004), a study conducted in Nepal stressed that the unavailability of public transport meant that many women would have to walk to reach health facilities for maternal services.

Lucas(2006), reported that "hospitals and health services are being rationalized into fewer, larger units serving wide areas and located in places that are difficult to reach without a car" (p. 802), accessing these facilities becomes particularly difficult for people who have to rely on public transport, leading to failed health appointments and associated delays in medical intervention.

Besides, the lack of available and reliable transport revealed in the study attests to the reason why there is delay in seeking maternal health services. This is corroborated in a study conducted in Zambia where seventy six percent of pregnant women had to walk to the clinic to receive care and fifty percent also had to walk for two hours or more to receive maternal services (Stekelenburg, 2004). Even when public transportation is available, there may be various barriers for people to use it in accessing healthcare facilities, including cost, unreliable bus schedules, long traveling times, bad weather conditions, and safety at bus stops (McCray 2000, 23-24).

Bad roads compound the problem of transporting pregnant women. In some districts, motorbikes are the main means of transport. The closeness of health workers to the health facility further calls for the good roads so as to transport patients from the hinter areas to facilities.

\subsection{Challenges with Transport Management Systems}

The study also revealed majority of health management staff affirming nonexistence of a transport operational management system and inadequate vehicles as being the major transport management challenge faced by the health management staff. Moreover procurement of new vehicles and motorbikes were also found from the study as a perceived antidote to challenges faced in managing transport resources in health delivery services. This revelation is however in sharp contradiction to TRANSAID's (2008) opinion, which emphasized that the accepted solution to transport difficulties in Africa is not to request more vehicles from international donors, but rather the provision of skilled personnel, good fleet management practices and properly functioning vehicles.

Furthermore, they stress (ibid) that the challenges faced by health management authorities in transport management are not caused by the lack of available transport, but rather by the shortage of skills, good management and properly functioning vehicles which cause problems with delivery of services and put lives at risk.

\subsection{Achievement of Millennium Development Goal (MDG) 5 in the Municipality}

Concerning the contribution of Public Private Partnership (PPP) to support the achievement of MDG 5, it was evidenced from the study that, this is of great importance. This is in harmony with Organization for Economic Co-operation and Development (OECD, 2010), where provision of policy guidance and technical support to countries is of great relevance. In addition PPP enable the public sector to get better value for money by transferring and reducing risk (e.g. of cost overruns) to those with the best expertise for managing it.

Again finding out the possibility of achieving zero maternal death in the municipality by the year 2015, health management staff perceived that it is likely to be achieved. This is however not being affirmed by African countries' MDG Africa Steering Group (2008) where there emerged success stories from across Africa with respect to all the MDG's with the exception of MDG 5 which faces huge challenges for its achievement.

\subsection{Conclusion and Implications}

This study explores the role of transport in the achievement of maternal death reductions. The critical role played by transport in the delivery of health services and for that matter maternal health services is of great relevance as was revealed from the findings of the study. On the issue of accessibility of transport, the findings revealed that the critical role played by transport in the delivery of health services and for that matter maternal health services 
is of great relevance. No skilled and trained personnel were found to be in place to manage whatever transport asset that existed at the Municipality to enhance an effective and efficient health delivery service. Also, most health management staff asserted that public private partnership would contribute significantly towards the improvement of transport in relation to the achievement of the Millennium Development Goal 5.

Based on the findings of this study, some relevant recommendations are made. There is the need for all stakeholders to be on board for the strengthening of public transportation system. It should not be left only in the hands of the private sector; government should establish strong policies to provide direction and support. The current Facility Based Ambulance System (FBAS) run by Ghana Health Service and National Ambulance Service (NAS) must be fused together to provide holistic national ambulance services for maternal services as a whole and health delivery service in general. Again cost of maternal transportation services in emergencies must be borne or absorbed by the National Health Insurance Scheme (NHIS). The municipal Health Service alone cannot meet the transportation needs of all patients including pregnant women. For speedy realization of the MDG 5 in the municipality, there is the need for collaborative effort to be established between the public and the private sector. Finally, substitute transport services could be organized with the assistance of new intelligent demand responsive technology: with such technology, pregnant women can be transported to health facilities in good time by a more efficient use of networked municipality fleet and ambulances system to reduce $2^{\text {nd }}$ phase delay instead of depending only upon public transportation system which fails in most times.

\section{References}

Airey, T. (1992). Transport as a factor and constraint in Agricultural production and marketing. World Bank Sub-Saharan Africa Transport Program, Rural Travel and Transport Project.

Babinard, J., and Roberts, P. (2006). Maternal Health and Child Mortality Goals: What can the Transport sector do? Transport Paper TP-12. The World Bank, Washington, DC.

Borghi J, Ensor T, Neupane BD \& Tiwari S. (2004). Coping with the Burden of the Costs of Maternal Health. Nepal Safer Motherhood Project, part of HMGN Safe Motherhood Programme, Options, DFID and HMGN, Kathmandu.

Cook, R., Dickens, B., Wilson, O., and Scarrow, S. (2001). Advancing safe motherhood through human rights. Geneva: World Health Organization.

Freedman, L. P., Waldman, R., Wirth, M., Rosenfield, A., and Chowdhury, M. (2004). Millennium Project Task Force on Child Health and Maternal Health Interim Report. [Online] Available: $\mathrm{http}: / /$ www.unmillenniumproject.org/html/tf4docs.shtm

Gelband H., Liljestrand, J., Nemer, N., Islam, M., Zupan, J., and Jhan, P. (2001). The evidence base for interventions to reduce maternal and neonatal mortality in low and middle-income countries (Commission on Macroeconomics and Health [CMH] Working Paper, No. 5). Geneva: WHO. [Online] Available: http://www.cmhealth.org/docs/wg5_paper5 (November 27, 2002)

Ghana Statistical Service, Ghana Health Service, Macro Int'l Inc. (2009). Ghana Maternal Health Survey. (2007), Calveton, Maryland, USA: GSS, GHS and Macro Int'1.

Hamlin, C. (2004). Preventing Fistula: Transport's Role in Empowering Communities for Health in Ethiopia. Back to Office Report, Addis Ababa Fistula Hospital.

Hanson, R. (2004). Transport Management Systems for Improved Access to Health - A Holistic Approach. Transaid Presentation, 8th TransNet Event - Workshop on "Mobility \& Health" (26.11.04)

Lucas, K. (2006). Providing transport for social inclusion within a framework for environmental justice in the UK. Transportation Research, Part A, 40: 801-809. http://dx.doi.org/10.1016/j.tra.2005.12.005

McCray, T. (2000). Delivering healthy babies: Transportation and healthcare access. Planning Practice and Research, 15 (1-2): 17-29. http://dx.doi.org/10.1080/00222938100770021

Nancollas S. (1999). From Camels to Aircraft: The development of a simple transport management system designed to improve health service delivery. Paper prepared for the WHO TECHNET Meeting. Geneva

Organization for Economic Co-operation and Development OECD. (2010). Dedicated public-private partnership units: A survey of institutional and governance architectures, Paris.

Ronsmans, C., and Graham, W. (2006). Maternal mortality: Who, when, where, and why. The Lancet 368 : 1189-1200. http://dx.doi.org/10.1016/S0140-6736(06)69380-X

Stekelenburg, J. (2004). Health seeking behavior and utilization of health services in Kalabo district, Zambia: 
Stichting Drukkerr C. Reganboog, Groningen.

Thaddeus, S., and Maine, D. (1994). Too far to walk: maternal mortality in context. Volume 38 (8):109-110 (abstract only online), Social science and medicine

TRANSAID. (2008). Intermediate Mode of Transport in Resource Poor Areas. TRANSAID Worldwide, London N1 9AP UK.

UNICEF. (2008). Progress for Children: A Report Card on Maternal Mortality.

United Nations Permanent Forum. (2006). Fast Facts on Maternal Mortality and Morbidity.

United Nations Population Fund. (2004). A Mother's Promise the World Must Keep. New York: UNFPA.

Wikipedia Home Page (2009). Millennium Development Goals. [Online] Available: www.wikipedia.com.com

World Bank. (1999). Safe motherhood and the World Bank: Lessons from 10 years of experience. Washington, DC: The World Bank.

World Bank. (2000). Rural roads and transport: Overview and conclusions from managing and financing rural transport infrastructure.

World Health Organization (WHO). (2001). maternal mortality in 1995: Estimates developed by WHO, UNICEF, UNFPA. Geneva: WHO.

World Health Organization. (1992). International Classification of Diseases, $10^{\text {th }}$ Revision.

World Health Organization. (2007). Maternal Mortality in 2005. Ghana Health Service Ashanti Region Report, 2009.

Table 1. Availability of Transport

\begin{tabular}{|l|l|l|l|l|}
\hline \multirow{2}{*}{ Rating } & \multicolumn{2}{|l|}{ Pregnant Women } & \multicolumn{2}{l|}{ Health Management } \\
\cline { 2 - 5 } & Frequency & $\mathbf{\%}$ & Frequency & \% \\
\hline Good & 212 & 55.8 & 11 & 36.7 \\
\hline Fair & 120 & 31.6 & 13 & 43.3 \\
\hline Poor & 48 & 12.6 & 6 & 20.0 \\
\hline Total & $\mathbf{3 8 0}$ & $\mathbf{1 0 0}$ & $\mathbf{3 0}$ & $\mathbf{1 0 0}$ \\
\hline
\end{tabular}

Source: Author's Field Data, 2010

Table 2. Type of Transport used in accessing MHS

\begin{tabular}{|l|l|l|l|l|}
\hline \multirow{2}{*}{ Transport Type } & \multicolumn{2}{|l|}{ Pregnant Women } & \multicolumn{2}{l|}{ Health Management } \\
\cline { 2 - 5 } & Frequency & $\mathbf{\%}$ & Frequency & \% \\
\hline Public Transport & 250 & 65.8 & 17 & 56.7 \\
\hline Walk & 110 & 28.9 & 8 & 26.6 \\
\hline Private Car & 14 & 3.7 & 2 & 6.7 \\
\hline Motor Bikes & 6 & 1.6 & 3 & 10.0 \\
\hline Total & $\mathbf{3 8 0}$ & $\mathbf{1 0 0}$ & $\mathbf{3 0}$ & $\mathbf{1 0 0}$ \\
\hline
\end{tabular}

Source: Author's Field Data, 2010

Table 3. State of Roads Linking Health Facility

\begin{tabular}{|l|l|l|l|l|}
\hline \multirow{2}{*}{ State of Roads } & \multicolumn{2}{|l|}{ Pregnant Women } & \multicolumn{2}{l|}{ Health Management } \\
\cline { 2 - 5 } & Frequency & $\mathbf{\%}$ & Frequency & \% \\
\hline Good & 206 & 54.4 & 11 & 36.7 \\
\hline Fair & 122 & 32.1 & 13 & 43.3 \\
\hline Poor & 52 & 13.7 & 6 & 20.0 \\
\hline Total & $\mathbf{3 8 0}$ & $\mathbf{1 0 0}$ & $\mathbf{3 0}$ & $\mathbf{1 0 0}$ \\
\hline
\end{tabular}

Source: Author's Field Data, 2010 


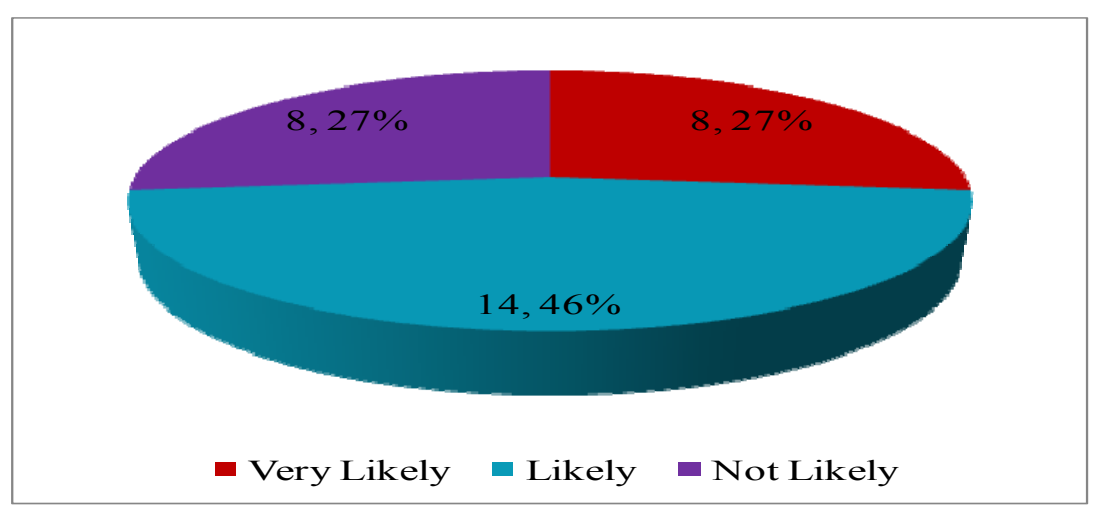

Figure 1. Possibility of Achieving Zero Maternal Deaths

Source: Author's Field Data, 2010

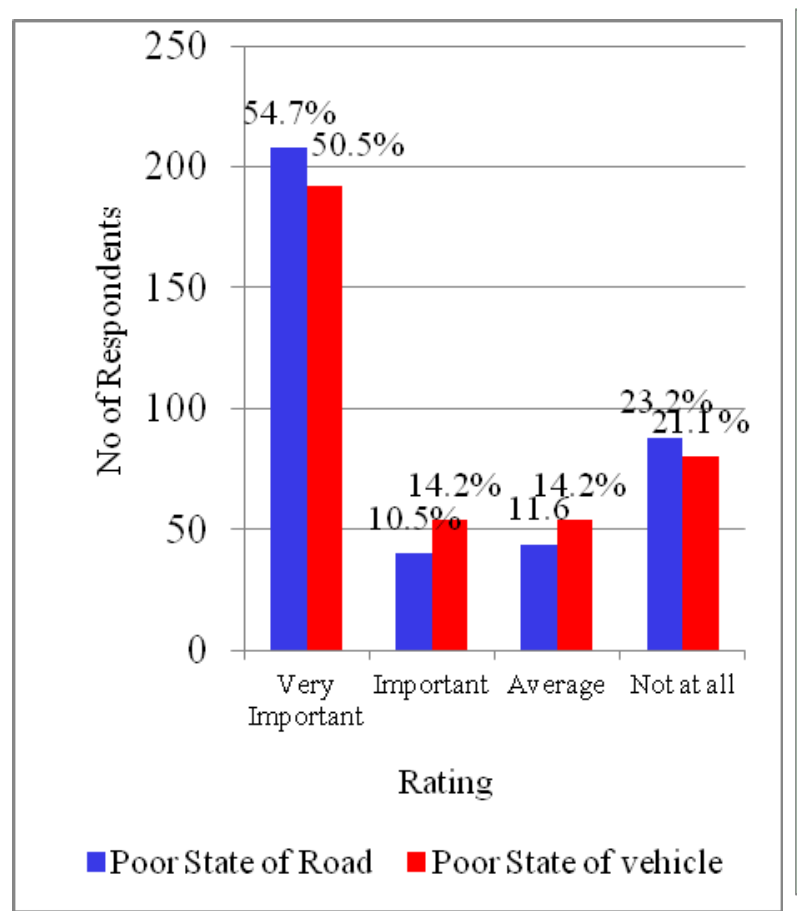

Pregnant Women

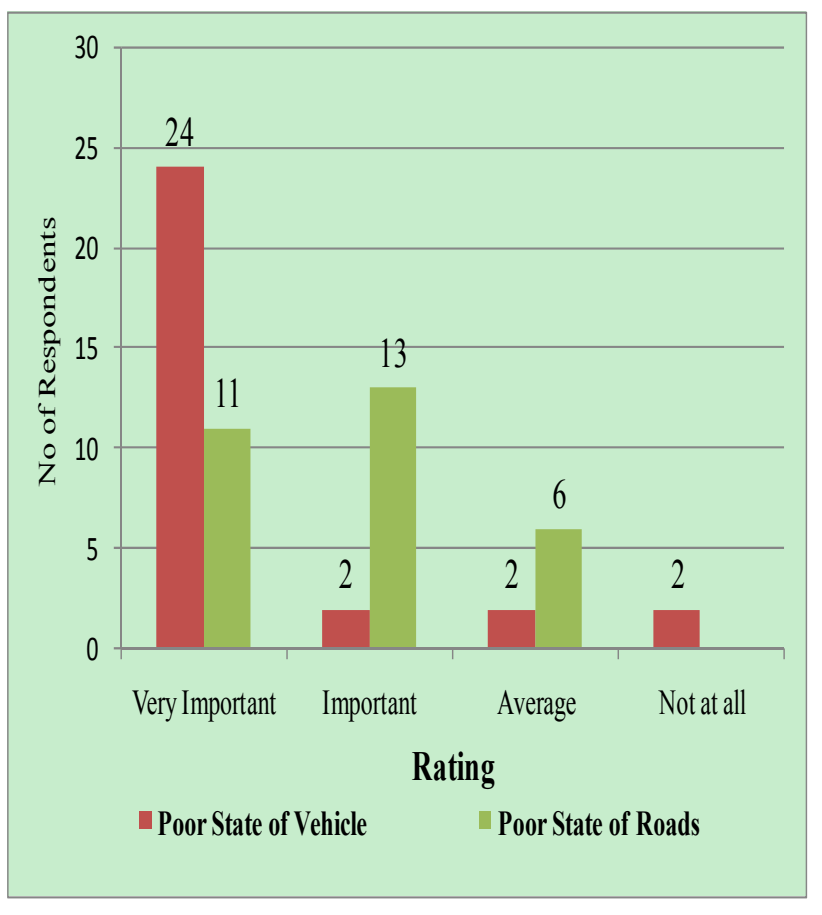

Health Management Staff

Figure 2. State of Vehicles and Roads as Maternal hazards

Source: Author's Field Data, 2010 


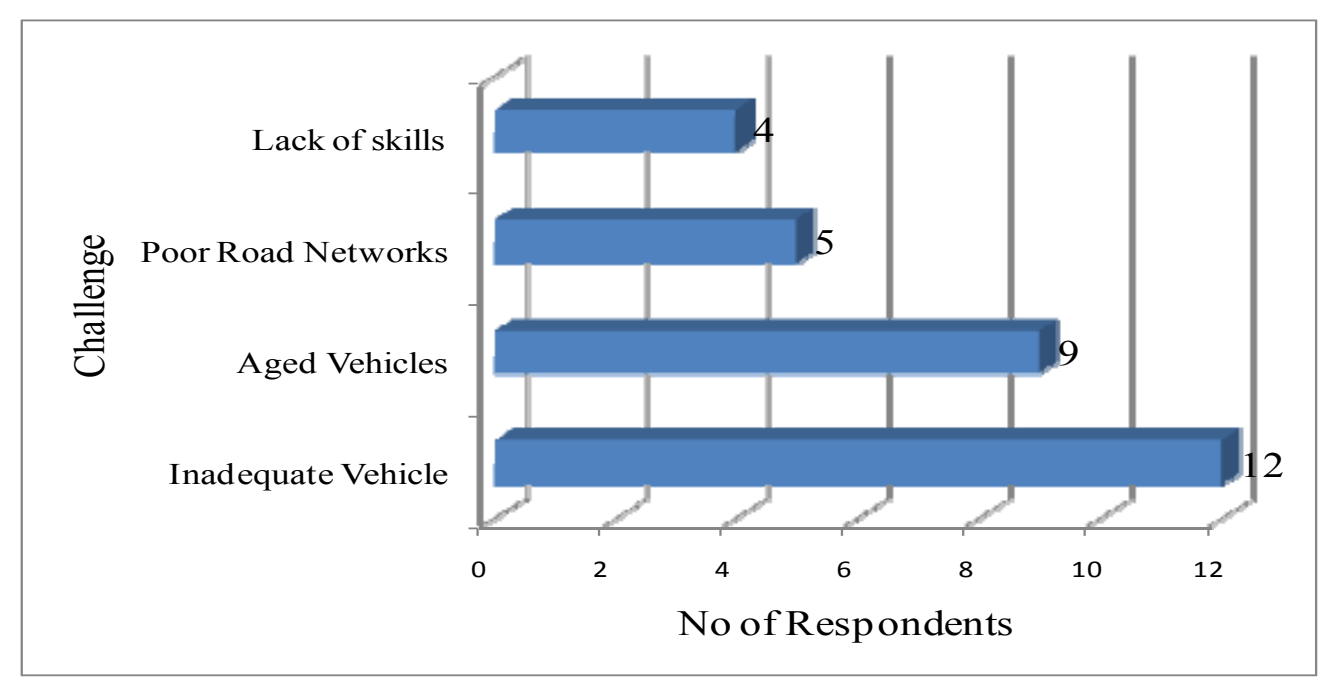

Figure 3. Transport Challenges

Source: Author's Field Data, 2010

\title{
APPENDIX I: SAMPLE INTERVIEW QUESTIONS FOR PREGNANT WOMEN
}

\author{
KWAME NKRUMAH UNIVERSITY OF SCIENCE AND TECHNOLOGY \\ SCHOOL OF BUSINESS
}

\section{INTRODUCTION}

This set of questions is to enable the researcher collect data that would enable him assess the role of Transport in the achievement of Maternal Mortality Reduction (MDG 5) in the Ghana Health Service of Asante Akim North Municipal, Ashanti Region

This exercise is purely academic. Your contribution by way of answering the questionnaire will be highly appreciated.

Questionnaire No..........

Facility..

Date.

\begin{tabular}{|c|c|c|c|c|}
\hline No & Question & Response & Code & Fieldname \\
\hline & Category of Respondent & PREGNANT WOMEN & 1 & pregnantwomen \\
\hline \multicolumn{5}{|c|}{ PART A } \\
\hline 1 & Age & $\begin{array}{l}18-25 \mathrm{yrs} \\
26-30 \mathrm{yrs} \\
31-35 \mathrm{yrs} \\
36-40 \mathrm{yrs} \\
40 \text { and above }\end{array}$ & & age \\
\hline 2 & No. of Children & $\begin{array}{l}\text { One } \\
\text { Two } \\
\text { Three } \\
\text { Four and above }\end{array}$ & & children \\
\hline 3 & Marital status & $\begin{array}{l}\text { Single } \\
\text { Married } \\
\text { Divorced } \\
\text { Co-habitation }\end{array}$ & $\begin{array}{l}1 \\
2 \\
3 \\
4 \\
\end{array}$ & marital \\
\hline 4 & Occupation & $\begin{array}{l}\text { Unemployed } \\
\text { Artisan }\end{array}$ & $\begin{array}{l}1 \\
2 \\
\end{array}$ & occupation \\
\hline
\end{tabular}




\begin{tabular}{|c|c|c|c|c|}
\hline & & $\begin{array}{l}\text { Formal } \\
\text { Trader } \\
\text { Other }\end{array}$ & $\begin{array}{l}3 \\
4 \\
5\end{array}$ & \\
\hline 5 & Income & $\begin{array}{l}\text { GH } \notin 10-50 \\
\mathrm{GH} \notin 51-100 \\
\mathrm{GH} \notin 101-150 \\
\mathrm{GH} \notin 151-200 \\
\mathrm{GH} \notin 200 \& \text { above }\end{array}$ & $\begin{array}{l}1 \\
2 \\
3 \\
4 \\
5\end{array}$ & income \\
\hline 6 & Educational level & $\begin{array}{l}\text { No education } \\
\text { Primary } \\
\text { JHS } \\
\text { SHS } \\
\text { Tertiary } \\
\end{array}$ & $\begin{array}{l}1 \\
2 \\
3 \\
4 \\
5\end{array}$ & Education \\
\hline 7 & $\begin{array}{l}\text { How regularly do you attend to } \\
\text { antenatal services? }\end{array}$ & $\begin{array}{l}\text { Regularly } \\
\text { Irregularly } \\
\text { Not at all }\end{array}$ & $\begin{array}{l}1 \\
2 \\
3\end{array}$ & regualarattendant \\
\hline 8 & How old is your pregnancy? & $\begin{array}{l}1^{\text {st }} \text { Trimester } \\
2^{\text {nd }} \text { Trimester } \\
3^{\text {rd }} \text { Trimester } \\
\end{array}$ & $\begin{array}{l}1 \\
2 \\
3 \\
\end{array}$ & trimester \\
\hline \multicolumn{5}{|c|}{ PART B } \\
\hline 1 & $\begin{array}{l}\text { Which of this sub- district are you } \\
\text { coming from? }\end{array}$ & $\begin{array}{l}\text { Agogo } \\
\text { Konongo/Odumasi } \\
\text { Juansa } \\
\text { Dwease/Praaso } \\
\text { Amantenaman } \\
\text { Other (specify) } \\
\end{array}$ & $\begin{array}{l}1 \\
2 \\
3 \\
4 \\
5 \\
6\end{array}$ & subdistrict \\
\hline 2 & $\begin{array}{l}\text { Availability of transport from your } \\
\text { community to the health facility? }\end{array}$ & $\begin{array}{l}\text { Good } \\
\text { Fair } \\
\text { Poor } \\
\end{array}$ & $\begin{array}{l}1 \\
2 \\
3 \\
\end{array}$ & transportavailable \\
\hline 3 & $\begin{array}{l}\text { Rate relevance of poor state of vehicles } \\
\text { as maternal hazard }\end{array}$ & $\begin{array}{l}\text { Very important } \\
\text { Important } \\
\text { Average } \\
\text { Not at all }\end{array}$ & $\begin{array}{l}1 \\
2 \\
3 \\
4\end{array}$ & badvehiclehazard \\
\hline 4 & $\begin{array}{l}\text { Why do you seek maternal services } \\
\text { here? Because it is: }\end{array}$ & $\begin{array}{l}\text { The nearest possibility to go } \\
\text { The best medical service to go } \\
\text { The cheapest service to go to } \\
\text { The best transport }\end{array}$ & $\begin{array}{l}1 \\
2 \\
3 \\
4\end{array}$ & seekservices \\
\hline 5 & $\begin{array}{l}\text { Which type of transport do you use } \\
\text { most for accessing maternal health } \\
\text { services? }\end{array}$ & $\begin{array}{l}\text { Public Transport (trotro) } \\
\text { Private Car } \\
\text { Motorbike } \\
\text { Walk }\end{array}$ & $\begin{array}{l}1 \\
2 \\
3 \\
4\end{array}$ & transporttype \\
\hline 6 & $\begin{array}{l}\text { How many transit trips do you make to } \\
\text { reach the health facility? }\end{array}$ & $\begin{array}{l}\text { One trip } \\
\text { Two trips } \\
\text { Three trips } \\
\text { Four trips }\end{array}$ & $\begin{array}{l}1 \\
2 \\
3 \\
4\end{array}$ & transittrips \\
\hline 7 & $\begin{array}{l}\text { Rate relevance of poor state of roads as } \\
\text { maternal hazard }\end{array}$ & $\begin{array}{l}\text { Very important } \\
\text { Important } \\
\text { Average } \\
\text { Not at all }\end{array}$ & $\begin{array}{l}1 \\
2 \\
3 \\
4\end{array}$ & badroadharzard \\
\hline 8 & $\begin{array}{l}\text { State of roads linking your community } \\
\text { to the health facility? }\end{array}$ & $\begin{array}{l}\text { Good } \\
\text { Fair } \\
\text { Poor }\end{array}$ & $\begin{array}{l}1 \\
2 \\
3 \\
\end{array}$ & roadstate \\
\hline 9 & $\begin{array}{l}\text { In case of obstetric emergency by what } \\
\text { means to call for an ambulance? }\end{array}$ & $\begin{array}{l}\text { Through network system } \\
\text { Through personal mobile phone } \\
\text { Sending for a health staff } \\
\text { Other (specify) }\end{array}$ & $\begin{array}{l}2 \\
3 \\
4\end{array}$ & meanstocall \\
\hline 10 & $\begin{array}{l}\text { Are you given priority for public } \\
\text { transportation to health facilities? }\end{array}$ & $\begin{array}{l}\text { Always } \\
\text { Sometimes } \\
\text { Never }\end{array}$ & $\begin{array}{l}1 \\
2 \\
3\end{array}$ & priority \\
\hline
\end{tabular}




\title{
APPENDIX II: SAMPLE INTERVIEW QUESTIONS FOR HEALTH MANAGEMENT STAFF
}

\section{KWAME NKRUMAH UNIVERSITY OF SCIENCE AND TECHNOLOGY}

\author{
SCHOOL OF BUSINESS
}

\section{INTRODUCTION}

This set of questions is to enable the researcher collect data that would enable him assess the role of Transport in the achievement of Maternal Mortality Reduction (MDG 5) in the Ghana Health Service of Asante Akim North Municipal, Ashanti Region

This exercise is purely academic. Your contribution by way of answering the questionnaire will be highly appreciated.

Questionnaire No..........

Facility......

Date.

\begin{tabular}{|c|c|c|c|c|}
\hline No & Question & Response & Code & Fieldname \\
\hline & Category of Respondent & $\begin{array}{l}\text { HEALTH MANAGEMENT } \\
\text { KEY INFORMANT }\end{array}$ & 1 & $\begin{array}{l}\text { healthmgt } \\
\text { keyinformants }\end{array}$ \\
\hline \multicolumn{5}{|c|}{ PART A } \\
\hline 1 & Occupation & $\begin{array}{l}\text { Medical Officer } \\
\text { Medical Assistant } \\
\text { Midwife } \\
\text { Health Administrator } \\
\text { Other (specify) }\end{array}$ & $\begin{array}{l}1 \\
2 \\
3 \\
4 \\
5\end{array}$ & Occupation \\
\hline 2 & Length of service & $\begin{array}{l}01-3 y r s \\
04-6 y r s \\
06-8 y r s \\
08-10 y r s \\
\text { Above } 10 \text { yrs }\end{array}$ & $\begin{array}{l}1 \\
2 \\
3 \\
4 \\
5\end{array}$ & lengthofservice \\
\hline 3 & Educational Level & $\begin{array}{l}\text { JHS } \\
\text { SHS } \\
\text { Tertiary } \\
\text { Post tertiary }\end{array}$ & $\begin{array}{l}1 \\
2 \\
3 \\
4\end{array}$ & education \\
\hline 4 & Age & $\begin{array}{l}25 y r s \text { and below } \\
26-30 y r s \\
31-35 y r s \\
36-40 y r s \\
41-45 y r s \\
\text { Above } 45 y r s\end{array}$ & $\begin{array}{l}1 \\
2 \\
3 \\
4 \\
5 \\
6\end{array}$ & age \\
\hline 5 & Gender & $\begin{array}{l}\text { Female } \\
\text { Male }\end{array}$ & $\begin{array}{l}1 \\
2\end{array}$ & Gender \\
\hline \multicolumn{5}{|c|}{ PART B } \\
\hline 1 & $\begin{array}{l}\text { Why do pregnant women seek maternal } \\
\text { services here? } \\
\text { Because it is: }\end{array}$ & $\begin{array}{l}\text { The nearest possibility to go } \\
\text { The best medical service to go } \\
\text { The cheapest service to go to } \\
\text { The best transport }\end{array}$ & $\begin{array}{l}1 \\
2 \\
3 \\
4\end{array}$ & seekservices \\
\hline 2 & $\begin{array}{l}\text { Type of transport use most by pregnant } \\
\text { women for accessing maternal health services }\end{array}$ & $\begin{array}{l}\text { Public Transport (trotro) } \\
\text { Private Car } \\
\text { Motorbike } \\
\text { Walk }\end{array}$ & $\begin{array}{l}1 \\
2 \\
3 \\
4\end{array}$ & transporttype \\
\hline 3 & $\begin{array}{l}\text { How many transit trips do pregnant women } \\
\text { make to reach the health facility? }\end{array}$ & $\begin{array}{l}\text { One trip } \\
\text { Two trips } \\
\text { Three trips } \\
\text { Four trips }\end{array}$ & $\begin{array}{l}1 \\
2 \\
3 \\
4\end{array}$ & manytransit \\
\hline 4 & $\begin{array}{l}\text { Rate relevance of unavailability of vehicles as } \\
\text { maternal hazard }\end{array}$ & $\begin{array}{l}\text { Very important } \\
\text { Important } \\
\text { Average } \\
\text { Not at all }\end{array}$ & $\begin{array}{l}1 \\
2 \\
3 \\
4\end{array}$ & rarevehicleharzrd \\
\hline
\end{tabular}




\begin{tabular}{|c|c|c|c|c|}
\hline 5 & $\begin{array}{l}\text { Rate relevance of poor state of vehicles as } \\
\text { maternal hazard }\end{array}$ & $\begin{array}{l}\text { Very important } \\
\text { Important } \\
\text { Average } \\
\text { Not at all }\end{array}$ & $\begin{array}{l}1 \\
2 \\
3 \\
4\end{array}$ & badvehicleharzard \\
\hline 6 & $\begin{array}{l}\text { State of roads linking your community to the } \\
\text { health facility? }\end{array}$ & $\begin{array}{l}\text { Good } \\
\text { Fair } \\
\text { Poor } \\
\end{array}$ & $\begin{array}{l}1 \\
2 \\
3\end{array}$ & roadstate \\
\hline 7 & $\begin{array}{l}\text { Rate relevance of poor state of roads as } \\
\text { maternal hazard }\end{array}$ & $\begin{array}{l}\text { Very important } \\
\text { Important } \\
\text { Average } \\
\text { Not at all }\end{array}$ & $\begin{array}{l}1 \\
2 \\
3 \\
4\end{array}$ & badroadharzard \\
\hline 8 & $\begin{array}{l}\text { In case of an obstetric emergency by what } \\
\text { means do you call for an ambulance? }\end{array}$ & $\begin{array}{l}\text { Through network system } \\
\text { Through personal call } \\
\text { Sending a health staff }\end{array}$ & $\begin{array}{l}1 \\
2 \\
3\end{array}$ & meanstocall \\
\hline \multicolumn{5}{|c|}{ Challenges } \\
\hline 1 & $\begin{array}{l}\text { Do you have transport management systems } \\
\text { in place? }\end{array}$ & $\begin{array}{l}\text { Yes } \\
\text { No } \\
\text { Don't Know }\end{array}$ & $\begin{array}{l}1 \\
2 \\
3\end{array}$ & transportsystem \\
\hline 2 & $\begin{array}{l}\text { Are your transport resources managed by } \\
\text { professionals? }\end{array}$ & $\begin{array}{l}\text { Yes } \\
\text { No } \\
\text { Don't Know }\end{array}$ & $\begin{array}{l}1 \\
2 \\
3 \\
\end{array}$ & resourcesmanaged \\
\hline 3 & $\begin{array}{l}\text { Do you have enough transport (ambulance) } \\
\text { for maternal services? }\end{array}$ & $\begin{array}{l}\text { Yes } \\
\text { No } \\
\text { Don't Know }\end{array}$ & $\begin{array}{l}1 \\
2 \\
3\end{array}$ & enoughambulance \\
\hline 4 & $\begin{array}{l}\text { Do you have budgeted funds for the running } \\
\text { of your transport resources? }\end{array}$ & $\begin{array}{l}\text { Yes } \\
\text { No } \\
\text { Don't Know }\end{array}$ & $\begin{array}{l}1 \\
2 \\
3\end{array}$ & budgetedfunds \\
\hline 5 & $\begin{array}{l}\text { In times of no vehicle, type of transport } \\
\text { means of pregnant women's timely referral? }\end{array}$ & $\begin{array}{l}\text { Seek regional support } \\
\text { Hire a car } \\
\text { Use motorbike/bicycle } \\
\text { Walk } \\
\text { Other (specify) }\end{array}$ & $\begin{array}{l}1 \\
2 \\
3 \\
4 \\
5\end{array}$ & novehicle \\
\hline 6 & $\begin{array}{l}\text { What is the most transport management } \\
\text { challenge you do face? }\end{array}$ & $\begin{array}{l}\text { Inadequate vehicles } \\
\text { Aged vehicles } \\
\text { Poor road network } \\
\text { Lack of skills } \\
\text { Other (specify) }\end{array}$ & $\begin{array}{l}1 \\
2 \\
3 \\
4 \\
5\end{array}$ & mostchallenge \\
\hline \multicolumn{5}{|c|}{ Health Workers perception } \\
\hline 1 & $\begin{array}{l}\text { Can zero maternal death (MDG 5) be } \\
\text { achieved in the district by } 2015 ?\end{array}$ & $\begin{array}{l}\text { Very likely } \\
\text { Likely } \\
\text { Not likely } \\
\text { Impossible }\end{array}$ & $\begin{array}{l}1 \\
2 \\
3 \\
4\end{array}$ & zerodeath \\
\hline 2 & $\begin{array}{l}\text { Do you have any transport management } \\
\text { problems with regards to achieving MDG5? }\end{array}$ & $\begin{array}{l}\text { Yes } \\
\text { No } \\
\text { Don't know }\end{array}$ & $\begin{array}{l}1 \\
2 \\
3\end{array}$ & transportproblems \\
\hline 3 & $\begin{array}{l}\text { What should be done most to manage } \\
\text { transport effectively with respect to maternal } \\
\text { health services? }\end{array}$ & $\begin{array}{l}\text { Procure more vehicles } \\
\text { Engage transport professionals } \\
\text { Outsource transport services } \\
\text { Provide good road networks } \\
\text { Other (specify) }\end{array}$ & $\begin{array}{l}1 \\
2 \\
3 \\
4\end{array}$ & publicprivate \\
\hline 4 & $\begin{array}{l}\text { Significance of public private partnership } \\
\text { support for transport to the achievement of } \\
\text { MDG } 5\end{array}$ & $\begin{array}{l}\text { Very important } \\
\text { Important } \\
\text { Average } \\
\text { Not at all }\end{array}$ & $\begin{array}{l}1 \\
2 \\
3 \\
4\end{array}$ & Public private \\
\hline
\end{tabular}

